\title{
The role of Interleukin 6, C Reactive Protein ,C3and C4 Complement in Immunopathogenesis of Myocardial Infarction
} Ahmed Methab Athab $(\mathrm{PhD})^{1}$,Mohammed Abdul-Daim Saleh $(\mathrm{PhD})^{2}$ and Ali Abbas Aboud Al-dulaimi(MSc) ${ }^{3}$

Abstract

Background:Coronary artery disease is the leading cause of premature death in the developed world and is estimated to become, by 2020, the major cause of death worldwide. Objective:To Evaluate the role of interleukin 6 and acute phase proteins in immunopathogenesis of myocardial infarction.

Patients and Methods: This study was conducted in Baquba Teaching Hospital in Diyala province .Ninety blood sample were collected from patients with myocardial infarction, 62 (68.9\%)were males and $28(31.1 \%)$ were females with age range (25-90) years, control group (35) patient, a males were $28(77.14 \%)$, and females were $8(22.86 \%)$ with age range (25-70) years.

Results: The results showed levels of Interlukine-6 was higher in patients $(47.44 \pm 30.50) \mathrm{pg} /$ $\mathrm{ml}$ than control $(37.13 \pm 12.08) \mathrm{pg} / \mathrm{ml}$ with no significant difference and the positivity of Creactive protein in patient group was $(81.3 \%)$ than control group was $(0 \%)$, with highly significant different, the level of $\mathrm{C} 3$ and $\mathrm{C} 4$ in present study was lower in patient than control group.The C3 complement level was (112.88) pg / $\mathrm{ml}$ which is lower than control group (121.48 \pm ) pg / ml ,while C4 level was (19.73) pg / $\mathrm{ml}$ also lower than control group (26.81) pg / $\mathrm{ml}$ and significant difference was noticed among $\mathrm{C} 4$.

Conclusion:We concluded that there is high level of IL-6 in patients with myocardial infarction and significantly high levels of C-Reactive Protein in patients of Myocardial infarction while showed there are low concentration levels of C3 and C4complement in patients with myocardial infarction.

Keywords: Myocardial Infarction, Interlukine-6, CRP , complement C3 and C4

Corresponding Author: athab69@yahoo.com

Received: $26^{\text {th }}$ December 2018

Accepted: $17^{\text {th }}$ February 2019

\section{Introduction}

Myocardial ischemia is a condition myocardial oxygen demand in the setting of a characterized by inadequate myocardial flow-limiting coronary stenosis (reduced perfusion ,may result from an increase in flow reserve, the predominant mechanism in 
stable angina) or a primary reduction in coronary blood flow due to thrombosis or vasoconstriction [1] .Coronary artery disease (CAD) is the leading cause of premature death in the developed world and is estimated to become, by 2020, the major cause of death worldwide[2]. Almost all myocardial infarction result from coronary atherosclerosis, generally with superimposed coronary thrombosis[3].

Interlukin-6 is the proinflammatory cytokines that produced from different cells such as fibroblast, mononuclear cells , mast cells and $\mathrm{T}$ lymphocytes cells [4], and a cording to studies, IL-6 contributes to the development of infarct size in the early phase of reperfusion; this contribution independent on neutrophil influx, IL-1 $\beta$ and TNF $\alpha$, tissue factor and fibrin [5]. C-Reactive Protein CRP is the first acute phase proteins, and is immunogenic protein that synthesis in liver from hepatocytes. This protein used in investigation on several diseases such as acute hepatitis, bacterial endocarditis and myocardial infarction, in high concentrations of this protein give as evidence of acute inflammation [6] and CRP leads to activation complement system through the classical pathway, lead to opsonization of pathogens and damaged cells[7].

The potential atherogenic role of the complement system, a main effector arm of immunity and inflammation, remains to be determined. The complement system interact with one another in 3 activation cascades known as the classic, the alternative, and the lectin pathways[8], (C3) is constitute (70)\% from complements proteins and consider more complement proteins concentration in serum, decrease concentration of $\mathrm{C} 3$ protein may cause repeated bacterial infections and acute inflammation[9]. Patients deficient in C3 protein are suffering from repeated bacterial infection [10]. Aim of this study was to investigate the possible role of CRP, IL 6, and complement $\mathrm{C} 3, \mathrm{C} 4$ as a candidate biomarker in patients with myocardial infarction.

\section{Patients and Methods}

The present study was conducted during period from $1 / 5 / 2015$ to $1 / 5 / 2016$. Ninety blood samples was collected from patients with acute myocardial infarction who were admitted to cardiac care unit at Baquba Teaching Hospital in Diyala province, the number of male [62] and female [28] within the age range between (25-95) years. Also collected [36] blood sample from healthy people and use them as a control group, from 36 control group a [28] were male and [8]were female within age range between (25-70) years. The study was approved from the ethics committee of the Institute and informed consent were obtained from patients.

We aspirated a $(5 \mathrm{ml})$ of venous blood from patients and healthy people included in the study, mediated by sterile syringes and region with draw the sterilized by $(70 \%)$ alcohol or Dettol, after the separation of serum by using centrifuge at rate of 3000 $\mathrm{r} / \mathrm{min}$ for [10] minutes. The separated serum distribute into eppendrof tube in equal amounts $(500 \mu 1)$ and these tubes keept in 
The role of Interleukin 6, C Reactive Protein ,C3and C4 Complement in Immunopathogenesis of Myocardial Infarction

deep freeze at temperature $\left(-80 \mathrm{C}^{\circ}\right)$ until use , each eppendrof tube used to avoid freezing and thawing of the model. Concentrations of (IL-6) determined by (ELISA) technique (IL6 Human ELISA Kit, catalog number: KHC0061 ) according to the manufacturer instructions, also serum had been tested for C-reactive protein by high sensitive Enzyme linked Immunosorbent Assay (ELISA kit, BioCheck, Inc 323) and according to manufacturer instructions , Radial Immunodiffusion assay was used for quantitative determination of $\mathrm{C} 3$ and $\mathrm{C} 4$ complement using Single radial immunodiffusion test. It was done according to manufacturer instruction (Sanofi diagnostic, Pasteur, France).

\section{Statistical analysis}

Continuous variables are reported as mean \pm standard deviation. Univariate analysis was performed to determine the association between these markers and with myocardial infarction. A P-value $<0.05$ was considered to be statistically significant, with a $95 \%$ confidence interval (CI). Calculations were done using SPSS version 20(39).

\section{Results}

\section{Estimation of (IL-6)}

There is high level of (IL-6) in patients with myocardial infarction $(47.4 \pm 30.5) \mathrm{pg} / \mathrm{ml}$ than control group $(37.13 \pm 12.08) \mathrm{pg} / \mathrm{ml}$ and without statistical significant different $(\mathrm{p}=0.23)$.

Table (1): Showed comparison level of (IL-6) between study groups.

\begin{tabular}{|c|c|c|c|c|}
\hline \multirow{2}{*}{\multicolumn{2}{|c|}{$\mathrm{Pg} / \mathrm{ml}$}} & \multicolumn{2}{|c|}{ Study group } & \multirow[t]{2}{*}{ P-value } \\
\hline & & Control & Patients & \\
\hline \multirow{2}{*}{ Serum IL-6 } & Mean & 37.13 & 47.44 & \multirow{2}{*}{$0.23^{\mathrm{NS}}$} \\
\hline & SD & 12.08 & 30.50 & \\
\hline
\end{tabular}

\section{Estimation of C-Reactive}

Protein CRP was positive in (61) patients of results of current study was highly significant MI from (75) patient and percentage (81.3\%) . so between study groups $(\mathrm{p}=0.001)$.

Table (2): show positivity of CRP within study groups.

\begin{tabular}{|c|c|c|c|}
\hline & & \multicolumn{2}{|c|}{ Study group } \\
\hline & & Control & Patients \\
\hline \multirow{4}{*}{ CRP } & Negative & 15 & 14 \\
\hline & $\%$ & $100 \%$ & $18.7 \%$ \\
\hline & Positive & 0 & 61 \\
\hline & $\%$ & $0 \%$ & $81.3 \%$ \\
\hline \multicolumn{2}{|c|}{ Total } & 15 & 75 \\
\hline
\end{tabular}


The role of Interleukin 6, C Reactive Protein ,C3and C4 Complement in Immunopathogenesis of

Myocardial Infarction

\section{Complement system $\mathrm{C} 3$ and $\mathrm{C} 4$ levels of}

Which showed there is low concentration of $\mathrm{C} 3$ and $\mathrm{C} 4$ in patients with myocardial infarction, the C3 level was (112.48) $\mathrm{mg} / \mathrm{dl}$ compared with control groups (121.48) $\mathrm{mg} / \mathrm{dl}$ with no significant differences $(\mathrm{p}=0.3)$, while the result showed low concentration of $\mathrm{C} 4$ in patients (19.73) $\mathrm{mg} / \mathrm{dl}$ compared to control group (26.81) $\mathrm{mg} / \mathrm{dl}$ with high significant different $(p=\leq 0.0001)$.

Table (3): Estimate concentration levels of $\mathrm{C} 3$ and $\mathrm{C} 4$ between study groups.

*NS=No significant

\begin{tabular}{|c|c|c|c|c|}
\hline \multirow{2}{*}{\multicolumn{2}{|c|}{$\overline{\mathrm{Mg} / \mathrm{Dl}}$}} & \multicolumn{2}{|c|}{ Study group } & \multirow[t]{2}{*}{$\mathrm{P}$ value } \\
\hline & & Control & Patients & \\
\hline \multirow[t]{2}{*}{$\overline{\mathrm{C}} 3$} & Mean & 121.48 & 112.88 & \multirow[b]{2}{*}{$0.3^{\mathrm{NS}}$} \\
\hline & SD & 29.484 & 44.58 & \\
\hline \multirow[t]{2}{*}{$\mathrm{C} 4$} & Mean & 26.81 & 19.73 & \multirow[b]{2}{*}{$0.001^{* * *}$} \\
\hline & SD & 8.677 & 6.092 & \\
\hline
\end{tabular}

** high significant

\section{Discussion}

\section{Estimation of of (IL-6)}

Results of our study showed high level of (IL-6) in patients with myocardial infarction without statistical significant differences. The results of our study were comparable with the study done in Iraq by Ibrahim et al.at 2012 which showed high level of (IL-6) concentration in patients of myocardial infarction with high significant differences $(p=<0.001)$ [11].Our study similar to another study done in Iraq by Al-Najay and Al-Jofy, 2009. showed the levels of (IL-6) increase significantly with patients of myocardial infarction[12].

Also our study agree by another many study ,such us Al-Ghurabie (2012) showed (IL-6) levels increase in patients of myocardial infarction that the IL6 increase the inflammatory process and thrombosis [13]. Also Nunez 1., study at (2012) showed the people that suffer from myocardial infarction and infection with cytomegalovirus have high level of (IL-6) that associated with higher mortality[14], and another study done by Abdulkarim showed the levels of (IL-6) increase with myocardial infarction, and there is a strong correlation with coronary angiography , that making the (IL-6) risk factor and good predictor for coronary artery diseases[15].

Patients with acute myocardial infarction and infected with cytomegalovirus have high levels of (IL-6) and play role and acceleration of cardiac damage[16] , AlGhurabie study showed the (IL-6) is a pro inflammatory cytokine can be stimulate heart damage during acute heart diseases[13].

Debrunner study and Su study, also showed the (IL-6) had significant correlation in patients with heart and blood vessels diseases and showed the high levels of (IL-6) in patients of myocardial infarction[17] [18] , therefore the IL-6 can be used as predictor 
The role of Interleukin 6, C Reactive Protein ,C3and C4 Complement in Immunopathogenesis of

Myocardial Infarction

factor for diagnosis myocardial infarction disease [19].

\section{Estimation of $\mathbf{C}$ - reactive protein}

Our study showed positive correlation of CRP within study group, positivity of CRP in patients of MI was (61) from (75) patient and percentage $(81.3 \%)$. so results of current study was significant between study groups $(\mathrm{p}=0.001)$.

Results of current study was agree with study of Ibrahim, (2012) that showed significantly high levels of CRP in patients of MI ( $p=0.001)$ [11] , the high levels of CRP can be used as predictor factor for coronary artery disease in patients with MI and unstable angina, also this rise can be lead to restenosis of artery after it has opened with cardiac catheterization[20].

The study done by Al-Najy, Al-Jofy and Abdulrazzaq revealed that high concentration of CRP in patients with MI with significant $(\mathrm{p} \leq 0.001)(12,21)$. Also Greenland, 2010 showed in acute MI and positivity of CRP is associated with several diseases such as (coronary heart diseases) [22]. Smimanek a. , 2011) study showed that CRP is inflammatory marker associated with development of heart diseases, atherosclrosis and mortality [23].

Many another studies like Mahajan, AlGurabei, Al-Sadi Calabro and zaikas studies mention the levels of CRP increase largely in acute MI and showed the CRP may play large role in modified inflammatory immune response after acute myocardial infarction and other forms of tissue injuries, and this refer the activation of complement system and thus tissue damage, so CRP can be activation complement system in damage of blood vessels . all these studies confirmed and agree with our study showed that high levels of CRP in coronary artery diseases ([24,5,25,26,27,28].

\section{Complement system C3 and C4}

Our study showed there is low concentration levels of $\mathrm{C} 3$ and $\mathrm{C} 4$ in patients with myocardial infarction, with no significant differencs $(p=0.3)$, while the result showed low concentration of $\mathrm{C} 4$ in patients high significant different $(p=\leq 0.0001)$. Our study agree with study of Paakkahen, (2009) that show decrease level of C3 its not effected in patients of acute myocardial infarction[29].

While another two studies done by (Delves, , 2006) and(Jinrong, 2006)[31]. are showed the activation of complement one cause in pathogenesis of myocardial infarction and Synthesize C3 and C4 in infarcted heart, although it synthesize in live and inflammatory cells[30,31].

Our study not agree with Hiad, study at 2011was mention the C3 complement concentration was high in most patients of acute coronary syndrome in first [24] hour of infarction[27], also not agree with IItumur, study (2005) and Micheal, 2002 showed in there study, that there is a marked increase in level of $\mathrm{C} 3$ in patients that suffering from MI they said that the C3 may be product through infarction cardiac cell[32,33].

While Delves, (2006). Mention in his study the activation of complement may be lead to inflamation of heart muscle during formation 
The role of Interleukin 6, C Reactive Protein ,C3and C4 Complement in Immunopathogenesis of

Myocardial Infarction

of membrane attack complex and generate (anaphylatoxins) [30] , so non-significant different may be because of the high level C3 is locally in necrotic heart muscle. Onte study showed the C3 play important role in systemic inflammations so $\mathrm{C} 3$ increase in patients that suffering from heart diseases and C3 associated with tissue damage in site of infracted heart so these two above studies agree with our study[34], according prevalence studies the $\mathrm{C} 3$ and $\mathrm{C} 4$ are inflammatory factor for predict for coronary artery disease, that refer to monitoring high and low levels of $\mathrm{C} 3$ and $\mathrm{C} 4$ with risk factor[35].

While Lim and Monowar study mentioned that the levels of $\mathrm{C} 3$ and $\mathrm{C} 4$ increase significantly in serum of acute MI patients comparable to control and the cause of these increased is due to synthesize complement components or adequate regulation, moreover, searcher pointed in his study the activation complement system happen after attack with MI and that was associated with inflammatory response and acute phase and degree of activation system may be associated with size of necrosis heart muscle , and decrease these levels in final days of MI. Increase concentration C3 play direct role in increase proliferation of vascular smooth muscle cell $[36,37,38]$.

\section{Conclusions}

We concluded that there is high level of IL6 in patients with myocardial infarction and significantly high levels of C-Reactive Protein in patients of Myocardial infaection while showed there are low concentration levels of $\mathrm{C} 3$ and $\mathrm{C} 4$ complement in patients with myocardial infarction.

\section{References}

[1]Prediman K. Shah and Erling Falk, pathophysiology of ischemic heart diseaseischemic heart diseasecardiology_3rd_Edition 2012.

[2]J. Alastair Innes and Simon Maxwell Coronary artery disease --cardio vascular disease -Davidson's Principles and Practice of Medicine 22nd edition 2016 page 230.

[3]Pierre Throux, ischemic heart disease Braunwald's Heart Disease A Textbook of Cardiovascular Medicine 9th ed.2011-page.

[4]Cojocaru, I.M. ; Cojocaru, M. ; Tanasescu, R. ; Iliescu, I. ; Dumitrescu, L. and Silosi, I. (2009). Expression of IL-6 Activity in patients with Acute Ischemic Stroke. Rom J Inter Med; 47(4): 393-6. [5]Jong, W.M. ; Ten, Cate H. ; Linnenbank, A.C. ; de Boer O.J. ; Reitsm, P.H. ; de Winter R.J. and Zunrbier, C.J. (2016). Reduced acute Myocardial Infarction ischemic-reperfusion injury in IL-6-deficient mice emploging a closef-chest model. Inflamm Res; 65(6): 489-99.

[6] Ingle, P. and Patel, D. (2011). C-Reactive Protein in Various Disease Condition-An Overview. Asian J. Pharm. Clin. Res; 4(1) : $1-5$.

[7]Hwang, J. ; Jiang, M. ; Lu, Y. and Wang, C. (2015). Precedent Fluctuation of serum HS-CRP to albumin ration and mortality risk of clinically stable Hemodialysis patients , Plos one J; 10(1) : 13-25. [8]Gongxiong and $\mathrm{Wu}$,Complement Regulator CD59 Protects Against. 
The role of Interleukin 6, C Reactive Protein ,C3and C4 Complement in Immunopathogenesis of

Myocardial Infarction

Atherosclerosis by Restricting the Formation of Complement Membrane Attack Complexcirculation Research-February 27, 2009 .

[9]Acosta, J. ; Qin, X. and Halperin, J. (2004). Complement and complement regulatory proteinsas potential molecular targets for vascular disease. Curr.Pharm. Des; 10: 203-211.

[10]Zabriskie,J. B.(2009). Basic component of the immune system. In:Essential clinical immunology. Zabriskie, J.B.(Edt). Cambridge university press. Cambridge, PP: 4.

[11]Ibrahhim, Ammal Esmaeel ; EL-Yassin Hadef Dhafer and AL-Janabi, Hamid Kareem Sachit. (2012). The Correlation Between Insulin , IL-6 and CRP in Acute Myocardial Infarction. . The Iraqi Postgraduate med J; 11(4): 536-541.

[12] Al-Najy, Mahdi Haider and Al-Joofy, Ikbal Khider.(2009). Relation of ImmuneInflammatory Markers (IL-6 ， Crpand ESRValue) With Prediction of Ischemic Heart Disease. The Iraqi Postgraduate Med J.; 8(4): 318-322.

[13]Al-Ghurabei, Batool H. (2012). Evaluation of serum anti-cardiolipin antibody, hs-CRP and IL-6 levels in cohort periodontitis as possible risk factors for cardiovascular diseases. J Bagh collage Dentistry ～24(2): 161-165. [14]Nunez, Julio ; Chilet, Marifina and Blasco, and Maria L. (2012). Low rate of detection of active cytomegalovirus (CMV) infection early following acute myocardial infarction. Atherosclerosis ; 222: 295-297. [15]AbdulKaeim, Nadia G.H. ; Taher,
Mohamed A. and Almarayati, Amal N. (2011). The Role of Some Inflammatory Markers (IL-6 and CRP) in the Pathogenesis of Acute Coronary Syndrome in Iraqi CCUb for Heart Diseases. Iraqi J Pharm Sci; 20(1): 43-94.

[16]Neal, B. (2008). Quantifying the Importance of Interleukin-6 for Coronary Heart disease. PLoS Med; 5: 84-85.

[17]Debrunner, M. ; Schuiki, E. and Minder, E. (2008). Proinflammatory cytokine in acute myocardial infarction with and without cardiogenic shock. Clin Res Cardiol; 97: 298-305.

[18]Su, Dongfang ; Li, Zhongxia ; Li, Xinrui. (2013). Association between Serum Interleukine-6 Concentration and Mortality in Patients with Coronary Artery Disease. Miao Wang ; $10: 7$.

[19]Fayed, Akram Muhammed ; Elsayed, Muhammad Nasr Eldeen ; Mahros, Atef Abd El Aziz ; Ayad, Mona Wagdy and Soliman, Ahmed Soliman. (2015). Study the Value of Interleukin-6 as Diagnostic Marker and Pridective of Cardic Events in ST Segment Evaluation Myocardial Infarction. J. American Science; 11(11): 132-143.

[20]Ridker, P.M. ; Bassuk, S.S. and Toth, P.P. (2003). C-reactive protein and risk of cardiovascular disease: Evidence and clinical application. Curr Atheroscler Rep ; 5: 341349.

[21]Abdulrazzaq, Noaman Abdullatef ; Jassim, Abdulbasit Insief and Kadhum, Ali Ibrahim. (2014). Evaluation of Certain Acute Phase Reactants in Patients with Acute 
The role of Interleukin 6, C Reactive Protein ,C3and C4 Complement in Immunopathogenesis of

Myocardial Infarction

Myocardial Infarction. The Iraqi

Postgraduate med J; 13(2): 176-180.

[22]Greenland, P. ; Aplert, J. S. ; Beller, G.A. ; BenJamin, E.J. ; Budoff, M.J. ; Fayad, G.A. ; Foster, E. Hlatky, M.A. ; Hodgson, J.M. ; Kushner, F.G. ; Laner, M.S. ; Taylor, A.J. ; Weintraub, W.S. and Wenger, N.K. (2010). ACCF/AHA guideline for assessment of cardiovascular risk in symptomatic adults : a report of the American College of cardiology foundation/American Heart Association task force on practice guidelines. Circulation; 122:2748-2764.

[23]Smimanke, Amanda M. ; Dowd, Jennifer Beam ; Pawelec, Graham ; Melzer, David ; Dutta, Ambarish ; and Aiello, Allison E.(2011). Seropositivity to Cytomegalovirus, inflammation, All-Cause and Cardiovascular Disease-Related Mortality in the United States. PLoS ONE ; 6:1-7.

[24]Mahajan, S.N. ; Bhavik, Patel P. ; Acharya, Sourya and Diwan, S.K. (2013). HS- C-Reactive Protein (HS-CRP): A Dependable Prognostic Marker in Acute Coronary Syndrome. Indian J. Applied Res; 3(7) :2249-555.

[25] AL-Sa'adi, Warka'a T. ; abdulmunem, Raed. and Jasim, Hussam S. (2015). Hs-CRP and Haptoglobin Levels in Iraqi Patients with Coronary Artery Disease. J Fac Med Baghdad; 57(1): 84-86.

[26]Calabro, P. ; Golia, E. and Yeh, E. T. (2010). Role C-reactive Protein in acute myocardial infarction and Stroke : possible therapeytic approaches. Curr pharm Biotechnol; 13:4-16.

[27]Hiad, Ali ; Najeeb, Basil ; Saleh, Ebtsam A. ; Haider, munther A Tlair and MT, EMAD J. M. (2011). Evaluation of the Complement (C3) in Patients with Acute Coronary Syndrome. The Iraqi Postgraduate med J.; 10 (1): 40-45.

[28] Ziakas, G. ; Konstantinos, C. ; Efthimia, Stavros, G. ; George, D. ; Giannoglou. (2011). Serial Measurements of Acute Phase Proteins in Patients with Acute Coronary Syndrome. Hellinic J Cardiol; 52: 293-98. [29]Paakkanen, R. ; Palikhe, A. ; Seppanen, M. ; Nieminen M.S. ; Vauhkonen, H. ; Saikku, P. ; Lokki M.L. and Sinisalo, J. (2009). Beneficial effect of clarithrmycin in patients with acute coronary syndrome and complement C4 deficiencies. Scand Cardiovasc J; 43: 395-401.

[30]Delves, P.J. ; Martin, S.J. ; Burton, D.R. and Roitt, I.M. (2006). Innate immunity: In Roitt's Essentials immunology, 11th ed., Blackwell, New York,:1-20.

[31]Jinrong, F.U. ; Guosheng, Lin ; Bin Zeng, Zhiwei W.U. ; Yanxia W.U. ; HOnggang C.H.U. ; Gangjian Q.I.N. ; Gong, liang ; Jinan. L.I. ; Xiang, Gan ; Xiaolan, Y.U. ; Chunhua, L.I. ; and Doxgxu Liu.(2006). Anti-ischemia/reperfusion of C1 inhibitor in myocardial cell injury via regulation of local myocardial C3 activity. Biochemical and Biophysical Research Communications; 350: 162-68.

[32] Iltumur, K. ; Karabulut A. ; Toprak G. and Toprak N. (2005). Complement 
The role of Interleukin 6, C Reactive Protein ,C3and C4 Complement in Immunopathogenesis of Myocardial Infarction

activation in acute coronary syndrome. APMIS ;113: 167-74.

[33]Michael, R. ; Cusack, M.B. and Michael, S. (2002). Systemic inflammation in unstable angina is the result of myocardial necrosis. J Am Coll Cardiol; 93:1917-23. [34]Onat, A. ; Uzunlar, B. ; Hergenc, G. ; Yazici, M. ; Sari, I. and Uyarel, H. (2005). Cross-sectional study of complement $\mathrm{C} 3$ as a coronary risk factor among men and women. Clin Sci (Lond); 108:129-35.

[35]Snyder, Michelle L. ; Shields, Kelly J. ; Korytkowski, Mary T. ; Sutton-Tyrrell, Kim and Talbott, Evelyn O. (2015). Complement protein $\mathrm{C} 3$ and coronary artery calcium in middleaged women with polycystic ovary syndrome and controls. Gynecol Endocrinol. ; 30(7): 511-515.

[36]Monowar, Tahmina ; Rahman, M.D. Sayedur ; Chowdhury, Osul Ahmed ; Shahabuddin, Md. ; Kundu, A.K. (2013). Serum Competent (C3 , C4) Levels in patients with acute Myocardial Ifarction. Res Desk; 2(1): 74-89.

[37]Lim, W. ; Crowther, M.A. and Eikelboom, J.W. (2006). Management of antiphospholipid antibody syndrome: a systematic review. JAMA; 295: 1050-7.

[38] Giasuddin, S.M. ; El Mahdawi, J.M and El Hassadi, F.M. (2007). Serum complement (C3 , C4) levels in patients with acute myocardial infarction and angina pectoris. BMRC Bull; 33: 98-102.

[39]Levesque, R. (2007). SSPS Programming and Data Management, 4th (Ed). Chicago ; pp: 522. 